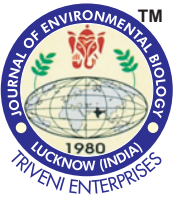

\title{
Evaluation of climate parameters of Black Sea coastline in the background of climate change
}

\author{
Authors Info \\ L. Lagidze ${ }^{1 *}$, L. Matchavariani ${ }^{2}$, \\ G. Metreveli ${ }^{3}$, N. Tsivtsivadze', \\ N. Paichadze ${ }^{5}$, Z. Gulashvili ${ }^{4}$ \\ and D. Svanadze ${ }^{5}$ \\ ${ }^{1}$ Department of Nature \\ Management, Faculty of Exact \& \\ Natural Sciences, Tbilisi State \\ University, Tbilisi- 0179, Georgia \\ ${ }^{2}$ Department of Soil Geography, \\ Faculty of Exact \& Natural \\ Sciences, Tbilisi State University, \\ Tbilisi- 0179, Georgia \\ ${ }^{3}$ Institute of Applied Ecology, \\ Faculty of Exact \& Natural \\ Sciences, TSU, Tbilisi- 0179, \\ Georgia \\ ${ }^{4}$ Department of Hydrometeorology, \\ Faculty of Exact \& Natural \\ Sciences, Tbilisi State University, \\ Tbilisi- 0179 Georgia \\ ${ }^{5}$ Department of Geography, Faculty \\ of Exact \& Natural Sciences, Tbilisi \\ State University, Tbilisi- 0179, \\ Georgia
}

*Corresponding Author Email : lamzira.laghidze@tsu.ge

Key words

Black Sea,

Climate change,

Meteorological data

Publication Info

Paper received : 20.08 .2016

Revised received : 21.06 .2017

Accepted : 27.06 .2017

\section{Abstract}

Aim: The Black Sea coastline of Georgia is evaluated as the region, characterized with highest grade of ecological vulnerability. For evaluating the climate change level of this region, the dynamics of climate parameters (temperature and precipitation) change during certain time period was accessed and analyzed.

Methodology: The study is based on the observation data of the National Environmental Agency and weather stations operating, in the past or at present, on the Black Sea coast. The data on air temperature (1930-2010) and sum of precipitations (1957-2006) for weather stations Batumi (air temperature 19312010), Poti (1930-2009) and statistical, climatologic and graphical analysis of treatment of many-year meteorological data were used for the study.

Results: According to linear approximation trend of 80 year observational data, average temperature in Batumi had increased by $0.70^{\circ} \mathrm{C}$. Meanwhile, average temperature in Poti had increased by $0.30^{\circ} \mathrm{C}$. The maximum temperature in Batumi had increased by $3.29^{\circ} \mathrm{C}$ and the minimal temperature also increased by $1.65^{\circ} \mathrm{C}$. The maximum temperature in Poti increased by $1.42^{\circ} \mathrm{C}$, and the minimal temperature also increased by $1.21^{\circ} \mathrm{C}$. The linear approximation trend of 50 years (1957-2006) observation data, the annual precipitation in Batumi decreased from $2650 \mathrm{~mm}$ to $2550 \mathrm{~mm}$, i.e. by $100 \mathrm{~mm}$. Meanwhile, the annual sum of precipitation in Poti increased from $1700 \mathrm{~mm}$ to $2150 \mathrm{~mm}$, i.e., precipitation increased by $450 \mathrm{~mm}$.

Interpretation: In the background of the global climate change, the temperature and amount of precipitation sharply changed, with pronounced warming and cooling periods. The study analysis gives opportunity to initiate and implement the relevant activities for maximum protection of natural ecosystems, economy, tourism and healthcare from a negative impact of climate change.
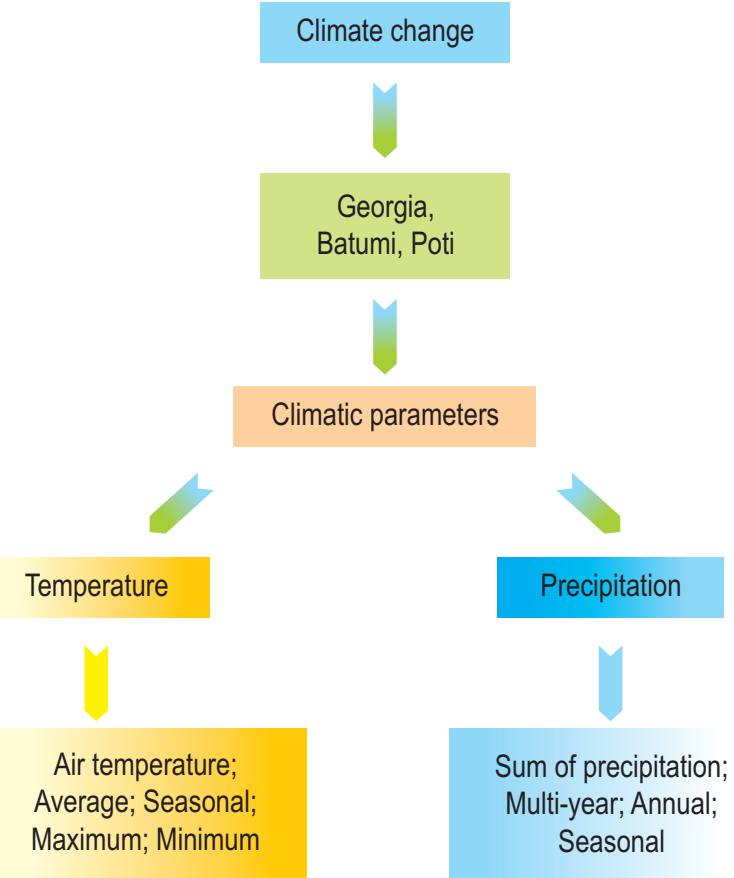


\section{Introduction}

Global climate change has been particularly noticeable since the 1970s, marked with the trend of the world annual average temperature change and intense climatic catastrophes (Thomas and Crowley, 2000; Smith et al., 2006). The climate change on the planet is expressed by the rise of average temperature and associated increase in the intensity of precipitation and frequency of extreme phenomena(Badel and Pandey, Mukand et al., 2014). The climate change leads to change in nature and ecosystems, many of which cannot adapt to the short term and get degraded. In addition, the risk of human diseases, including the spread of epidemics increases. The harmful outcome of the greenhouse effect becomes more diverse and intense from year to year, demanding urgency to find the solution to this problem (Bates et al., 2008).

In the background of global warming, the change of the regional climate has special peculiarities, which are important in regions located in a warming or cooling border area. It is known that warming and cooling trends due to climate change can be seen in the Black Sea basin. The limit between these opposite processes maybe found on the territory of Georgia (Tavartkiladze and Shengelia, 1999).In the border zone, warming or cooling is not a monotonous process near the border, either in warming or cooling zone. Rather, there are small areas with a clearly seen temperature change in the opposite direction (Beritashvili and Meskhia, 2007). Such a phenomenon is observed on the territory of Georgia as well, thus making it difficult to give a real picture of climate change.

The accomplished studies evidence a change in major climatic parameters on the whole territory of Georgia. In particular, the statistical data of the weather stations evidence the change in the average and extreme air temperatures and sum of precipitations, both in west and east Georgia (Nikolaishvili et al., 2015). Forecast for the same climatic parameters suggests that these changes will be more dramatic in future (Lagidze et al., 2015).

Studies carried out on the territory of Georgia have identified regions particularly sensitive to climate change (Shvangiradze and Metreveli, 2008). Together with three other regions, the Black Sea coastline is of particular importance due to the rising sea level and increased frequency and intensity of stormy events, which, in the area adjacent to the city of Poti particularly, is aggravated due to rise of river Rioni (Pachauriand Meyer, 2014).

Generally, the coastline, notwithstanding its location, is particularly sensitive to the climate change. In this respect, the Black Sea coast of Georgia is not an exception, with the rising sea level and increased frequency and intensity of storms. As recent studies suggest (the trend of change in the mean annual air temperature, precipitation according the Georgia's Second (2009) and Third (2015) National Communications to the UNFCCC), the Black Sea is most vulnerable ecosystem in Georgia in terms of climate change needing immediate adaptation measures (Janelidze, 2015). The major reasons for the climate change in Georgia are the circular processes, relief of the country, abundant water resources and the influence of Black Sea (Beritashvili et al., 2010).

Circulation processes forming the Black Sea climate: The climate of the Black Sea coast and its water body is formed under the influence of physical-geographical, radiation and circulation factors. Particularly important are geographical location of the Black Sea, air masses of different origins penetrating the area, and relief of the surrounding land (Tatashidze, 2000).

Owing to the geographical location of the Black Sea, the air circulates in almost all directions on its water surface. The air masses from north-west, west and south-west penetrate from the Atlantic Ocean and the Mediterranean, Continental air masses of tropical and moderate latitudes penetrate from south-west and north-west, and only Continental air masses (from Arctic, moderate latitudes and Tropical masses) penetrate from the north, north-east and south-east. The air masses coming from different regions are transformed on the Black Sea surface as marine air masses (Javakhishvili,1987).

Weather in the Black Sea region is formed through the cyclones, also common on the Sea itself. These are mostly regenerated cyclones, often coming from the Mediterranean. In summer, as a result of the Atlantic air flow, a strong layer or a rain cloud is formed, leading to precipitation and, sometimes, hurricane. Such precipitation is typical for the Bulgarian Black Sea coast, particularly, in the north side of Varna Gulf. On the east and south coasts, due to increased humidity and air instability, the precipitation sometimes causes natural calamities. Precipitation also happens due to the Mediterranean air masses mostly penetrating the Black Sea region during winters. The air masses penetrating from the Mediterranean result in higher temperature on the Black Sea in winter. Consequently, a snow cover is a rarity in most regions in the south and eastern part of the coast. The influence of the Continental air masses on the Black Sea climate is diversified. During warm periods, the Continental air masses cause high temperature in the coastal regions and may cause drought. High temperatures are recorded in the periods when heated Continental Tropical air from North Africa and Asia Minor, Eastern Europe and deserts and semi-deserts of Central Asia reaches the area.

\section{Materials and Methods}

The observation data of the National Environmental Agency and weather stations operating, in the past or at present, on the Black Sea coast were used for the study. The data on air 
temperature (1930-2010) and sum of precipitations (1957-2006) for weather stations Batumi (air temperature 1931-2010), Poti (1930-2009) and statistical, climatologic and graphical analysis of treatment of many-year meteorological data were used for the study (Nikolaishvili, 2014).

\section{Results and Discussion}

In order to identify the changes in air temperature, the observation data were divided into equal (20-year-long) periods. Using this data on the air temperature, we drafted tables showing (1) series of the average air temperatures of 20 -year-long periods for monthly and average annual values and (11) analysis of maximum and minimum temperature values in the 10-year-long periods (Fig. 1-14).

Batumi : Batumi is an administrative center of the Autonomous Republic of Ajara and is located 2-3 $\mathrm{m}$ above sea level on the Black Sea coast, on Kakhaberi Valley. The analysis of the table (Fig. 1) shows that under the influence of the global climate change, the average annual temperature (in 20-year-long periods) in Batumi from 1931 to 2010 changed from $6.28^{\circ} \mathrm{C}$ to $23.56^{\circ} \mathrm{C}$. In these periods, both, the maximal and minimal, temperature values changed, though little, but sufficient to indicate the climate change in particular warming and cooling. As the observation data of Batumi weather station suggest, the seasonal and annual values of average air temperature in the climatic periods on the background of the climate change, changed as follows (Fig. 2).

During I-IV periods, increase in temperature was found in all of seasons: in winter by $0.43^{\circ} \mathrm{C}$, in spring by $0.97^{\circ} \mathrm{C}$, in summer by $0.45^{\circ} \mathrm{C}$ and in autumn by $0.57^{\circ} \mathrm{C}$.

Fig. 3 shows the values of average air temperature in different periods during 1931-2010 was influenced by seasonal changes (in 20-year-long periods, between the most recent and preceding climatic periods).

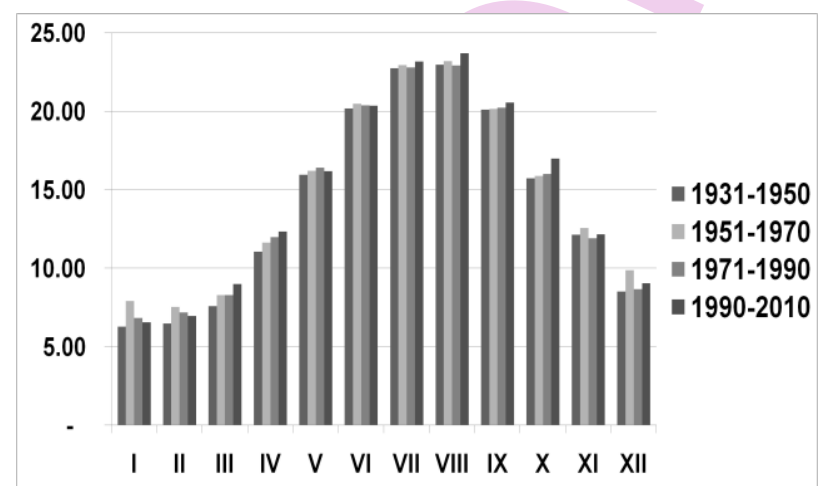

Fig. 1 : Batumi: Annual distribution of average temperature in 1931-2010 (during 20-year-long period)
During 1931-2010, the average air temperature during 20-year-long periods (between the latest and preceding climatic periods) increased, except II and III periods (when the same values decreased by $0.26^{\circ} \mathrm{C}$ ), while the average annual temperature increased by $0.61^{\circ} \mathrm{C}$ for the whole period. As the observation data of Batumi weather station suggest (Fig. 4), the average annual temperature (in 1931-2010) changed from $14.37^{\circ} \mathrm{C}$ to $14.81^{\circ} \mathrm{C}$ during 10 -year-long periods (eight periods).

Between these periods, there was a temperature change (warming and cooling), in particular, in the I and II periods, the average temperature decreased by $0.36^{\circ} \mathrm{C}$, from II to III period the average temperature increased by $0.65^{\circ} \mathrm{C}$, the temperature decreased by $0.01^{\circ} \mathrm{C}$ in the III-IV periods, it decreased by $0.23^{\circ} \mathrm{C}$ from the IV to $\mathrm{V}$ period, increased by $0.13^{\circ} \mathrm{C}$ in the $\mathrm{V}$-VI periods, decreased by $0.16^{\circ} \mathrm{C}$ from the VI to the VII period, and increased by $0.42^{\circ} \mathrm{C}$ from the $\mathrm{VII}$ to the $\mathrm{VIII}$ period. i.e., for 80 years, the temperature increased by $0.44^{\circ} \mathrm{C} / 80$ years.

As the observation data of Batumi weather station suggest, for 80 years, the maximum temperature (Fig. 5) changed from $31.30^{\circ} \mathrm{C}$ to $34.59^{\circ} \mathrm{C}(1931-2010)$ during 10 -yearlong period, with the temperature increase by $1.11^{\circ} \mathrm{C}$ in the first four periods, i.e., from 1931 to 1971 (a 40-year-long period) and fall of $0.73^{\circ} \mathrm{C}$ in $1971-1990$, while from 1990 through 2010 , the temperature increased significantly (by $2.91^{\circ} \mathrm{C}$ ), i.e., for 80 years (1931-2010), the maximum temperature increased by $3.29^{\circ} \mathrm{C}$.

During 10-year-long period, as the observation data of Batumi weather station suggest (1931-2010), the minimum temperature values based on the average annual data (Fig. 6), changed from $-3.30^{\circ} \mathrm{C}$ to $-1.65^{\circ} \mathrm{C}$.

In these periods (eight periods), the picture of minimum temperature changes (rise, fall) was a mixed one, i.e., for 80 years (1931-2010), the minimum temperature increase of $1.65^{\circ} \mathrm{C}$ was observed.

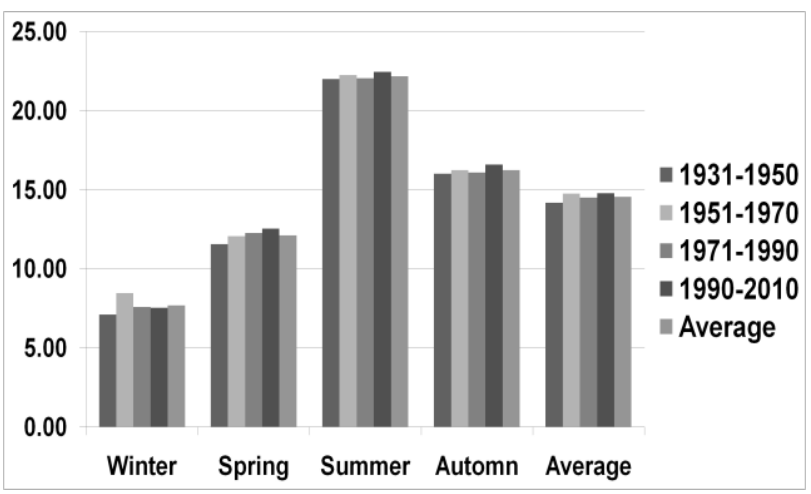

Fig. 2 : Batumi: Changes in average seasonal values of air temperature during 20-year-long period (1931-2010) 


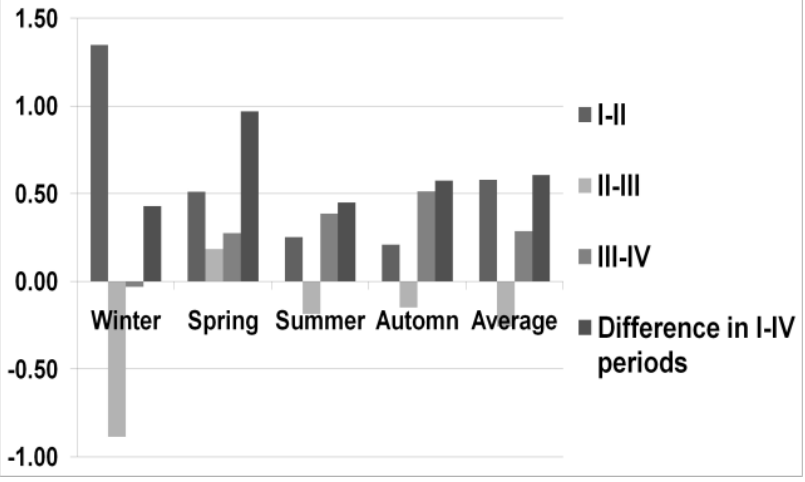

Fig. 3 : Batumi: Changes in average seasonal values of air temperature during 20-year-long periods, between the most recent and preceding climatic periods (1931-2010)

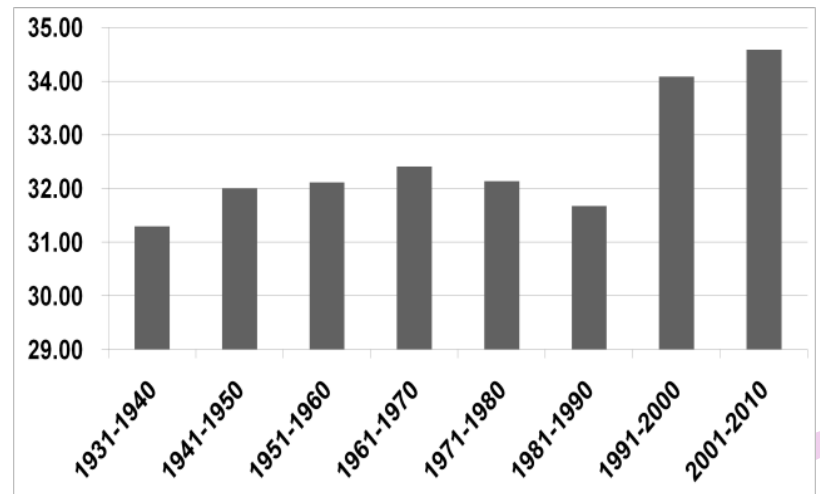

Fig. 5 : Batumi: Maximum air temperature in 1931-2010 (during 10-yearlong periods)

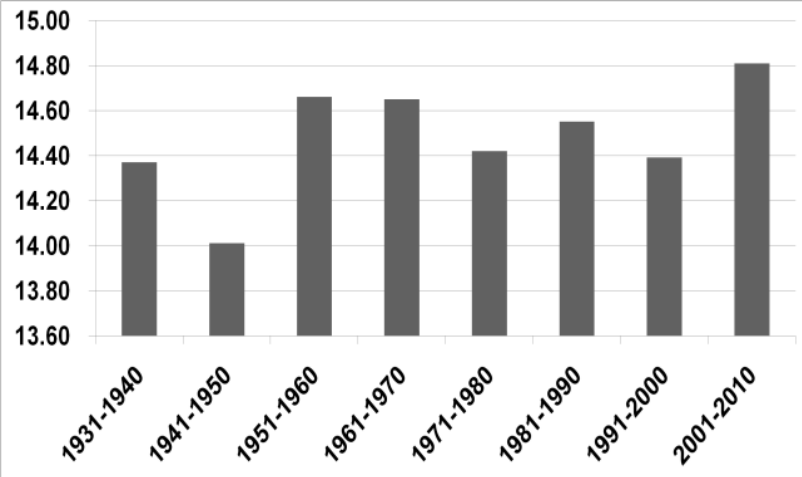

Fig. 4 : Batumi: Distribution of average temperature in 1931-2010 (during 10 -year-long periods)

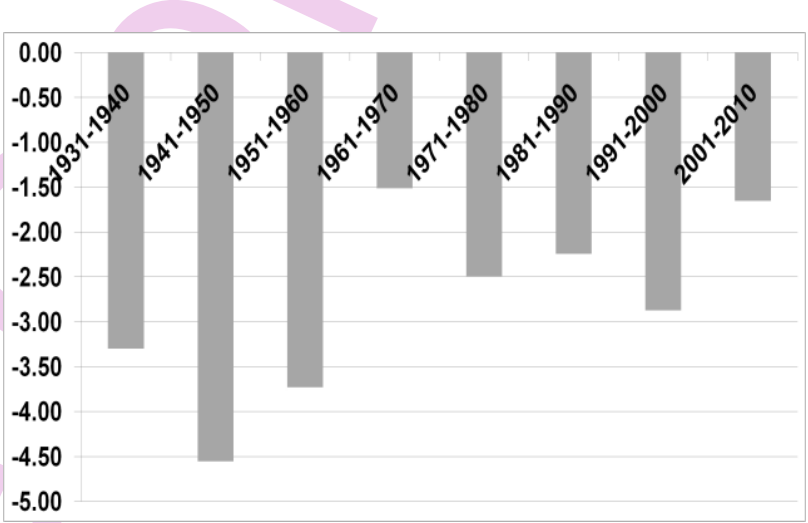

Fig. 6 : Batumi: Minimum air temperature in 1930-2009 (during 10 -year-long periods)

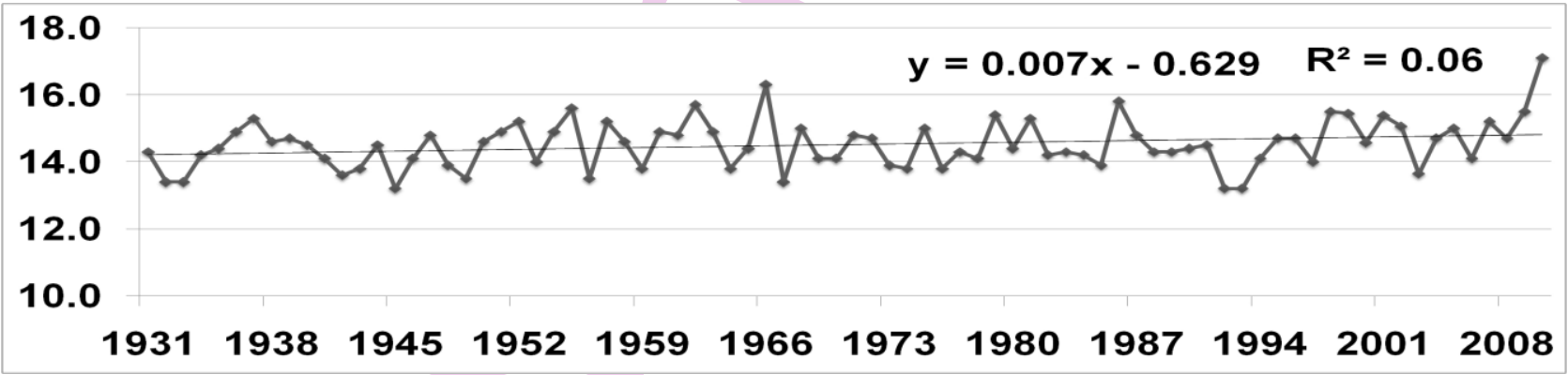

Fig. 7 : Batumi: Dynamics of average annual air temperature in 1931-2010

Based on the observation data of Batumi weather station, the values of average annual temperature changes are shown in Fig. 7. During this period of 1931-2010 (in the whole period, the average annual temperature changed from $14.3^{\circ} \mathrm{C}$ to $17.1^{\circ} \mathrm{C}$ ), while as per the linear approximation trend, the average temperature increased from $14.2^{\circ} \mathrm{C}$ to $14.9^{\circ} \mathrm{C}$, i.e. during 80 years, the temperature increased by $0.7^{\circ} \mathrm{C}$.

Poti : Poti is located in the basin, which is bordered by the river Rioni in the north and by the Black Sea and Paliastomi Lake in the west. The city is isolated from the Sea and the Lake with a series of sand dunes, and with water-protecting barriers from the river. The height of the water-protecting barriers following the 75 years of operation and owing to the tectonic subsidence, decreased by $0.4 \mathrm{~m}$ resulting in the increased risk of catastrophic flooding of the city because of land tectonic subsidence and current eustatic processes. The situation was further aggravated as a result of a $13 \%$ rise in the average flow of the river Rioni from 1930 to present.

The analysis of Fig. 8 shows that under the influence of the global climate change(data of Poti weather station), the 
average temperature (during 20-year-long periods) from 1930 to 2010 changed from $5.93^{\circ} \mathrm{C}$ to $24.31^{\circ} \mathrm{C}$ (with the amplitude of $18.38^{\circ} \mathrm{C}$ ). I-IV Periods throughout (except for the II period) was observed with rise in average temperature by $0.22^{\circ} \mathrm{C}$.

The observation data of Poti weather station suggest (Fig. 8), and the comparison of 20-year-long periods during 19302009 shows that the minimal average winter temperature was during the III period $\left(5.71^{\circ} \mathrm{C}\right.$ ) and maximal was in the IV period (in August) $\left(24.31^{\circ} \mathrm{C}\right)$. The minimum air temperature in spring was in the I period $\left(8.36^{\circ} \mathrm{C}\right)$ and maximum was in the $I I$ period $\left(16.60^{\circ} \mathrm{C}\right)$.

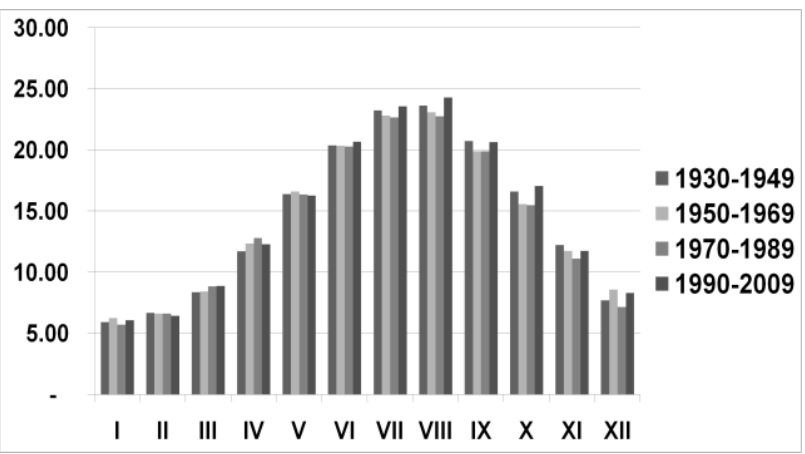

Fig. 8 : Poti: Average annual air temperature in 1930-2009 (during 20year-long periods)

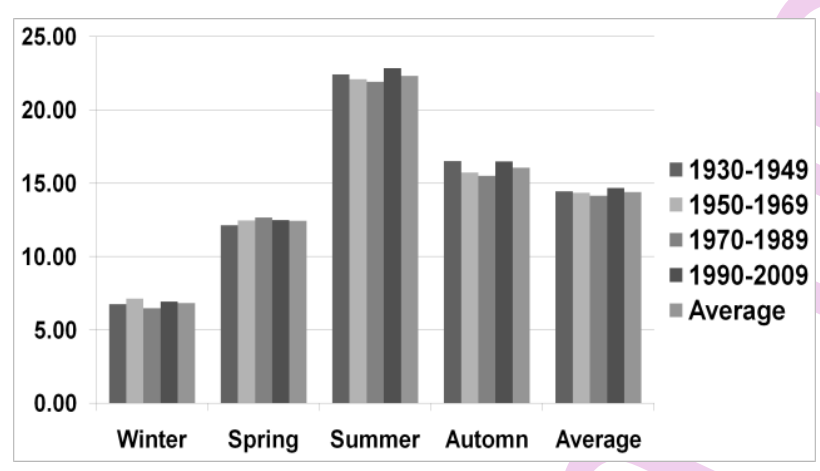

Fig. 10 : Poti: Changes in average seasonal values of air temperature during 20-year-long periods (1930-2009)

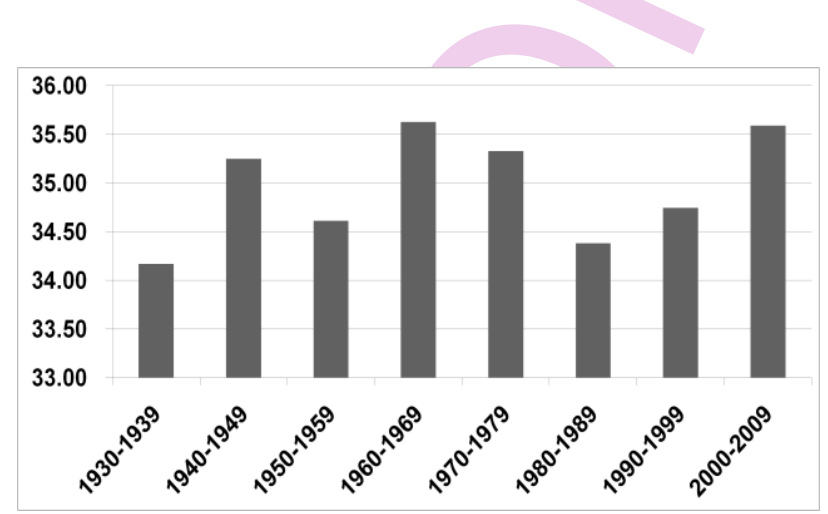

Fig. 12 : Poti: Maximum air temperature during 1930-2009 (10-yearlong periods)
The minimum air temperature in summer was in the III period $\left(20.20^{\circ} \mathrm{C}\right)$ and maximum was in the IV period $\left(24.31^{\circ} \mathrm{C}\right)$. The minimum air temperature in autumn was during the III period $\left(11.11^{\circ} \mathrm{C}\right)$ and maximum was in the I period $\left(20.74^{\circ} \mathrm{C}\right)$.

During these periods, both the maximal and minimal temperature values changed evidencing the climate change, in particular warming and cooling. As the observation data of Poti weather station suggest (Fig. 9), the average annual temperature (in $1930-2009$ ) changed from $14.37^{\circ} \mathrm{C}$ to $14.88^{\circ} \mathrm{C}$ during the 10 year-long period (eight periods).

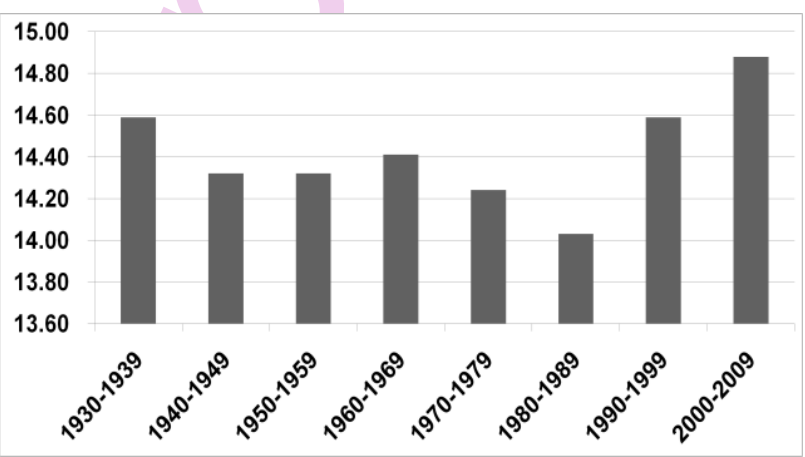

Fig. 9 : Poti: average annual air temperature in 1930-2009 (during 10year-long periods)

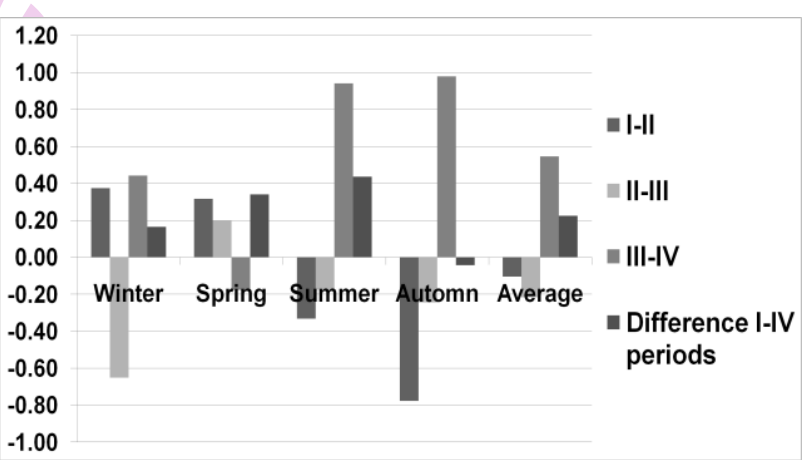

Fig. 11 : Poti: Changes in average seasonal values of air temperature $\left(t^{\circ} \mathrm{C}\right)$ during 20-year-long periods, between the most recent and preceding climatic periods (1930-2009)

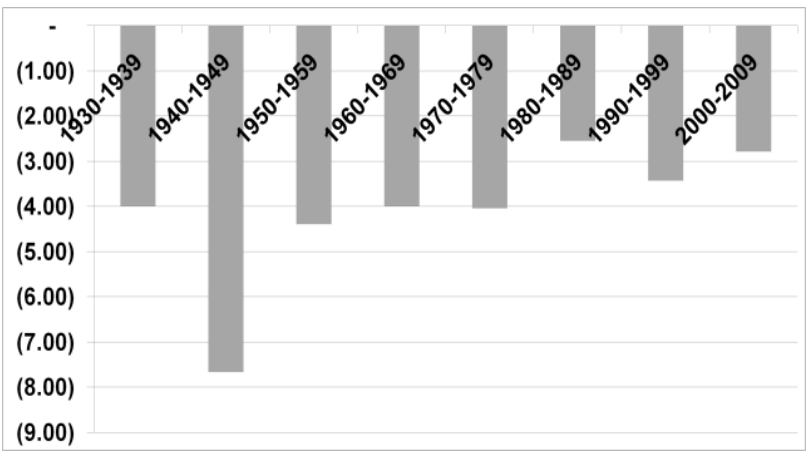

Fig. 13 : Poti: Minimum air temperature in 1930-2009 (during 10-yearlong periods) 


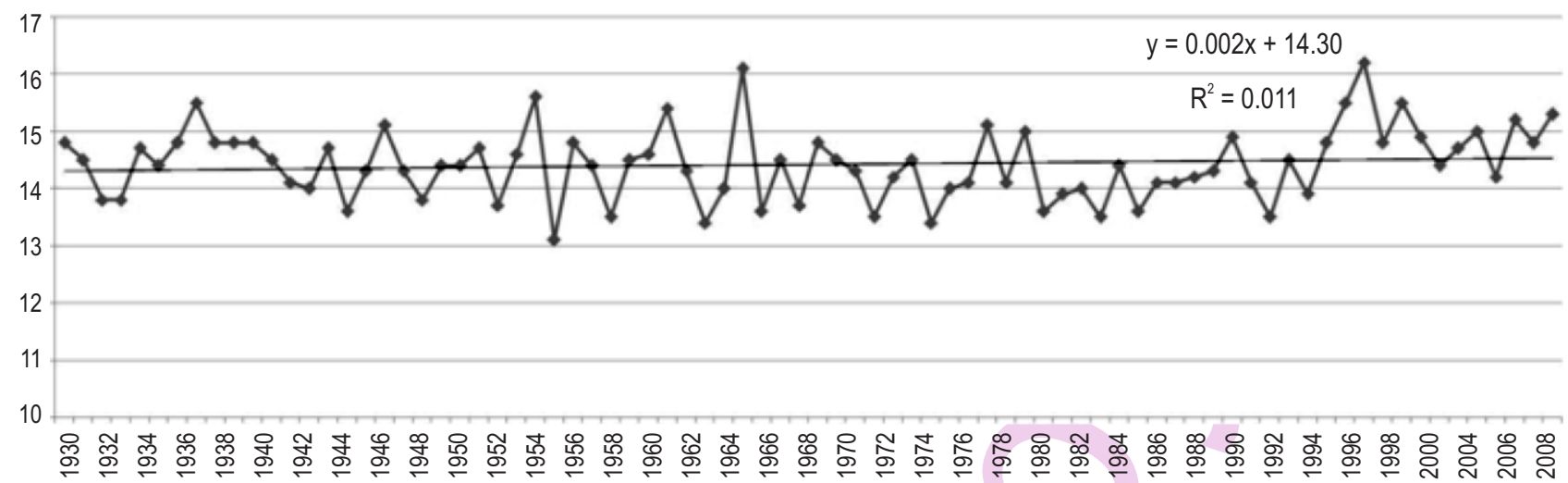

Fig. 14 : Poti: Dynamics of average annual air temperature in 1930-2009

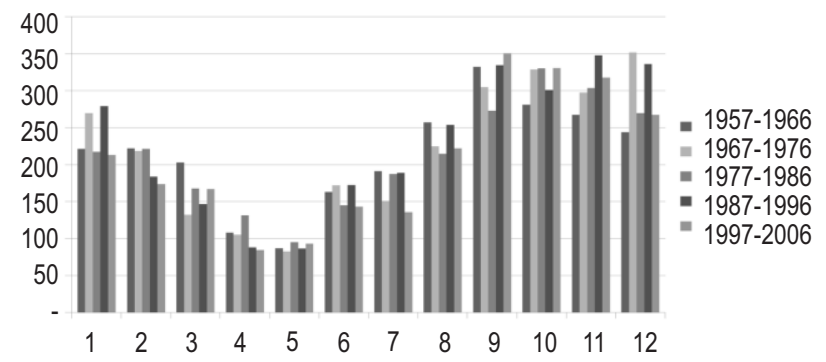

Fig. 15 : Batumi: Changes in the sum of precipitation in different months (1957-2006)(during 10-year-long period)

Between these periods, there was a temperature change (warming and cooling), in particular, from I to II period, the average temperature decreased by $0.27^{\circ} \mathrm{C}$, the temperature from II to III period did not change, the temperature increased by $0.09^{\circ} \mathrm{C}$ from III to IV period, decreased by $0.17^{\circ} \mathrm{C}$ from IV to $\mathrm{V}$ period, decreased by $0.21^{\circ} \mathrm{C}$ in V-VI periods, increased by $0.56^{\circ} \mathrm{C}$ in VIVII periods, and increased by $0.29^{\circ} \mathrm{C}$ during VII- VIII periods, i.e. during 80 years, the temperature increased by $0.29^{\circ} \mathrm{C}$.

The average temperature data of 10 -year-long 8 periods (1930-2009) suggest that the minimum temperature of $14.03^{\circ} \mathrm{C}$ and maximum of $14.88^{\circ} \mathrm{C}$ were observed in VI and VIII period, respectively.

The observation data of Poti weather station was analyzed in order to show the seasonal changes of the average air temperature. We have drawn tables (based on 20-year-long periods), and classified data in four climatic periods. The data about the average annual temperature and about the seasonal changes between the climatic periods is given in Fig. 10 .

During $1931-2010$, the temperature increased by $0.16^{\circ} \mathrm{C}$ in winter season; by $0.34^{\circ} \mathrm{C}$ in spring, by $0.44^{\circ} \mathrm{C}$ in summer and decreased by $0.04^{\circ} \mathrm{C}$ in autumn.

Analysis of Fig. 11 shows that during 1930-2009, the average values of air temperature in different periods are subject to seasonal changes (in 20-year-long periods, between the latest and preceding climatic periods), The average annual temperature in winter increased by $0.17^{\circ} \mathrm{C}$. Temperature increase was observed in all four periods, except in II-III periods. There was an increase in average temperature in spring, except in III-IV periods, while the average annual temperature in the whole period increased by $0.34^{\circ} \mathrm{C}$. During summer, in the I-II and II-III periods, the temperature decreased by $0.33^{\circ} \mathrm{C}$ and $0.17^{\circ} \mathrm{C}$, respectively, while up to III-IV periods, the temperature increased by $0.94^{\circ} \mathrm{C}$, with increase of $0.44^{\circ} \mathrm{C}$ in the whole period. In autumn, in the whole period, the temperature decreased by $0.04^{\circ} \mathrm{C}$.

During 1930-2009, the average annual air temperature (between the most recent and preceding climatic periods), decreased by $0.10^{\circ} \mathrm{C}$ from I to II period, further decreased by $0.22^{\circ} \mathrm{C}$ from the III to the IV period and increased by $0.55^{\circ} \mathrm{C}$ in IIIIV periods. As a whole, the average temperature increased by $0.23^{\circ} \mathrm{C}$

The observation data of Poti weather station suggest that the maximum temperature experienced a sharp change (increase and decrease) in different 10-year-long periods (Fig. 12). For 80 years $(1930-2009)$ period, the increase of the maximum temperature of $1.42^{\circ} \mathrm{C}$ was observed.

The observation data of Poti weather station shows that during the 10-year-long period (1930-2009) (Fig. 13), the minimum temperature values changed from $-4.00^{\circ} \mathrm{C}$ to $-2.79^{\circ} \mathrm{C}$ (the minimum value in II period and maximum value in $\mathrm{VI}$ period). During these eight periods, the picture of minimum temperature changes was a mixed one: the temperature change (rise, fall) was observed and for 80 year (1930-2009) period the minimum temperature increase of $1.21^{\circ} \mathrm{C}$ was seen.

Based on observation data of Poti weather station fluctuation of the average annual temperature during the past 80 years is shown in Fig. 14. The linear approximation trend showed that during this period (1930-2009), despite a slightly expressed warming trend, climate warming had not reached alarming scales 


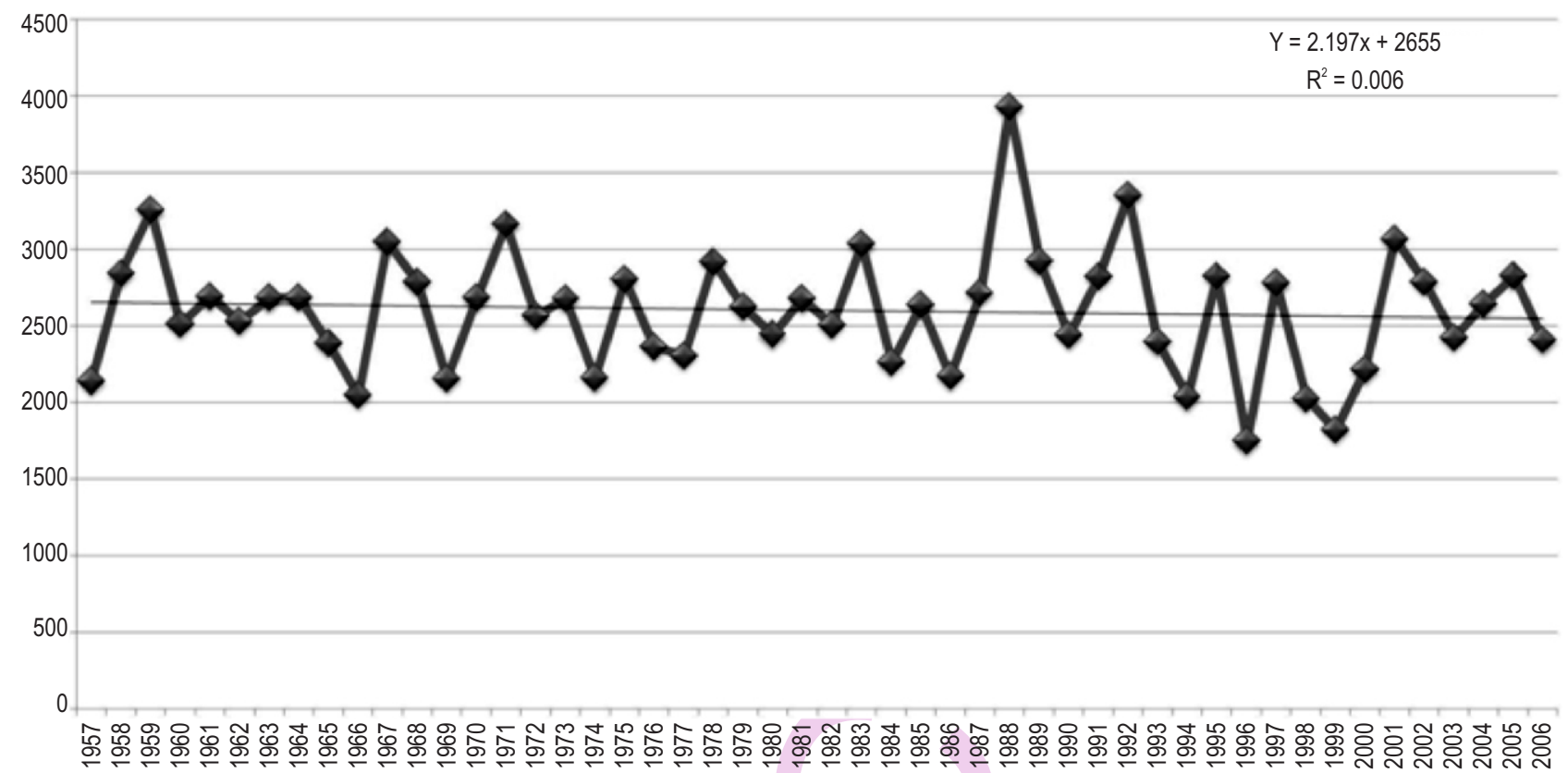

Fig. 16 : Batumi: Annual course of the sum of precipitation in 1957-2006

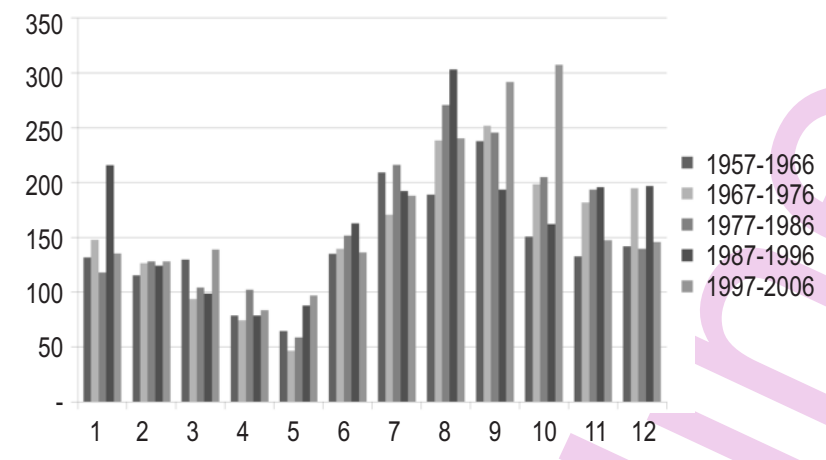

Fig. 17 : Poti: Changes in the annual sums of precipitation in different months (1967-2006) (in 10-year-long periods)

(the annual temperature in the whole period varied from $14.8^{\circ} \mathrm{C}$ to $15.3^{\circ} \mathrm{C}$ ), while the linear approximation trend, the average temperature deviated from $14.3^{\circ} \mathrm{C}$ to $14.6^{\circ} \mathrm{C}$, i.e. for 80 year period, the temperature increased by $0.3^{\circ} \mathrm{C}$.

Precipitation : With the annual distribution of precipitation, the territory of Georgia is full of contracts caused by the geographical location (the country is located between the Black and Caspian Seas) on the one hand and by the fact that the territory of the country is dissected with high ridges and deep gorges in different directions. Major role in precipitation formation is played by the Black Sea. Major role in formation of the climate of the Black Sea coastal zone is played by the atmospheric precipitation and air temperature (Beritashvili and Chogovadze, 2007).

An important role in the weather formation of the Black Sea coastal zone is played by the Western process. Sharp weather changes and abundant atmospheric precipitations are associated with the penetration of air masses from the west; 30 $35 \%$ of the precipitation caused by this process, fall in Georgia. The precipitation is particularly abundant during the double-side penetration. The wave mixes and convectional processes in the south of the Trans-Caucasia also result in particularly abundant precipitation. The Sea coastal line of Ajara is characterized by abundant precipitation, while the amount of precipitation drastically fall in the north. Daily maximum precipitation is in Batumi region. The absolute maximum of the maximum daily precipitation is $352 \mathrm{~mm}$. The duration of precipitation is always longer in the cold periods as compared to the warm periods of the year (Javakhishvili, 1987).

Study analysis : The dynamics of the changes of the atmospheric precipitation in the coastal zone of the Black Sea was studied by using observation data of the weather stations of 1957-2006, in particular, of such major indicators of precipitation, suchas monthly and annual sums. The study used the observation data of the weather stations of Poti. The dynamics of precipitation change was studied for each point during different seasons and during 10-year-long periods. The materials of observation over the annual sum of precipitation in different periods are given diagrams (Fig. 15-18).

Batumi : The materials of observation over the annual sum of precipitations during different periods are given in the table and diagrams (Fig. 15-16).

The study analysis (Fig. 15) showed that under the influence of global climate change, in Batumi in a 50-year-long 


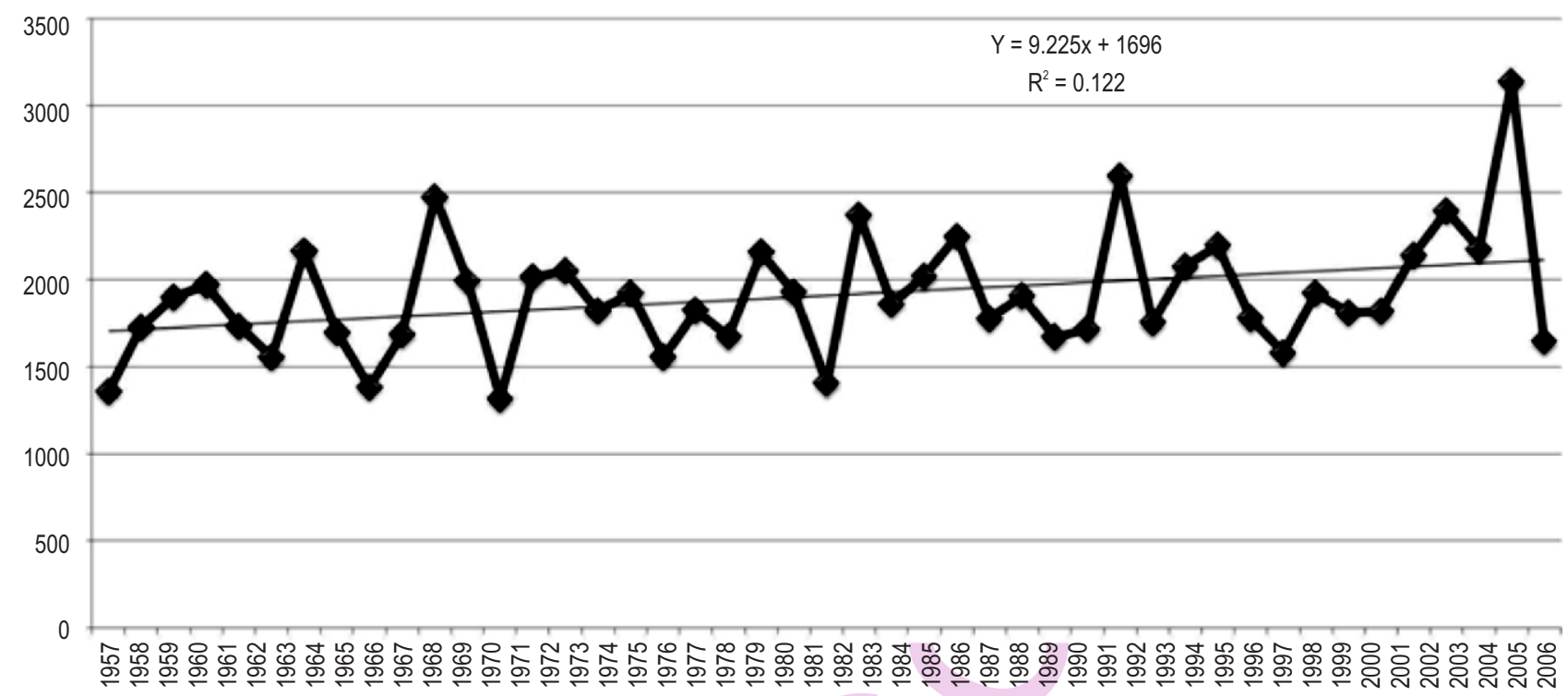

Fig. 18 : Poti: Annual course of the sum of precipitation in 1957-2006

period from 1957 to 2007, the amount of precipitation (in 10-yearlong periods) changed from $83 \mathrm{~mm}$ to $351 \mathrm{~mm}$. Accordingly, during the 50 -year-long period, the annual precipitation increased by $78 \mathrm{~mm}$.

The 50 years (1957-2006), observation data of precipitation is shown in Fig. 16 clearly indicates a sharp change in the sum of precipitation in recent period. By the linear approximation trend, the annual precipitation decreased from $2650 \mathrm{~mm}$ to $2550 \mathrm{~mm}$, i.e. for 50 years, the total precipitation decreased by $100 \mathrm{~mm}$.

Poti : The materials of observation over the annual total precipitation in different periods is given in Fig. 17-18.

The study analysis (Fig. 17) showed that under the influence of global climate change, in Poti from 1957 to 2007, the sum of precipitation (in 10-year-long periods) changed from 47 $\mathrm{mm}$ to $307 \mathrm{~mm}$. Accordingly, during 50-year-long period, the annual total sum increased by $323 \mathrm{~mm}$.

For 50 years (1957-2006), the materials of observation over the sum of precipitation is shown in Fig. 18, which clearly shows a sharp change in the sum of precipitation of the recent period. As the linear approximation trend suggests, the annual sum of precipitation increased from $1700 \mathrm{~mm}$ to $2150 \mathrm{~mm}$, i.e. for 50 years, the sum of precipitation increased by $450 \mathrm{~mm}$.

The global climate change, occurring during the last century, has produced a definite effect also on the large-scale circulation processes ongoing in the atmosphere because changes in the thermal regime of underlying surface (ocean and land) causes with corresponding changes in the circulation processes.

In the background of the global climate change, the temperature and amount of precipitation sharply changed, with warming and cooling periods.

\section{Acknowledgment}

This study is funded by Shota Rustaveli National Science Foundation within the scope of grant "Modern Methods of the Joint Problem Realization for Shore Protection and Hydropower" (\#AR/220/9-120/14).

\section{References}

Bates, B.C., Z.W. Kundzewicz, S. Wu and J.P. Palutikof, Eds.: Climate Change and Water.Technical Paper of the Intergovernmental Panel on Climate Change, IPCC Secretariat, Geneva, p. 210 (2008).

Beritashvili, B. and I. Chogovadze: About the influence of global warming on circulation processes over the Caucasian Ridge: Publishing House of RAS, Geographical Series, No. 2, pp. 101-103 (2007).

Beritashvili, B., N. Kapanadze and I. Chogovadze: Assessment of climate response In Georgia to Global warming: Tbilisi (2010).

Beritashvili, B. and A. Meskhia: A century of temperature anomalies in Georgia: The works of Hydro Meteorological Institute of Georgia, 111, 144-151 (2007).

Crowley T.J.: Causes of climate change over the past 1000 Years. Science, 289, 270-277(2000).

Georgia's Second National Communication to the United Nations Framework Convention on Climate Change. National Climate Research Centre, Tbilisi (2009).

Georgia's Third National Communication to the United Nations 
Framework Convention on Climate Change. National Climate Research Centre, Tbilisi. (2015).

Janelidze, Z.: Black Sea Coastline of Georgia: Tbilisi (2015).

Javakhishvili, S.: Climatology of Georgia: Tbilisi University Press (1987).

Lagidze, L., L. Matchavariani, N. Tsivtsivadze, N. Khidasheli, N. Paichadze, N. Motsonelidze and M. Vakhtangishvili: Medical aspects of atmosphere pollution. J. Environ. Biol., 36, 101-107 (2015)

Nikolaishvili, D., V. Trapaidze, B. Kalandadze, T. Mamukashvili and M. Sharashenidze: Complex evaluation of climate change - an example from Georgia's landscapes. J. Environ. Biol., 36, 43-49 (2015).

Pachauri, R. and L. Meyer: Climate Change: Summary report, Contribution of Working Groups I, II and III to the Fifth Assessment
ReportIPCC, Geneva, Switzerland (2014).

Shrestha, S., M.S. Badel and V.P. Pandey: Climate Change and Water Resources: CRC Press, Taylor \& Francis Group, Boca Baton London New York. (2014).

Shvangiradze, M. and G. Metreveli: Vulnerability assessment of Black Sea coastline of Georgia: Georgia's Second National Communication under the United Nations Framework (2008).

Smith, T., X. Yin and A. Gruber: Variations in annual global precipitation (1979-2004), based on the Global Precipitation Climatology Project $25^{\circ}$ analysis: Geophysical Research Letters 33, (2006).

Tatashidze, Z.: (Under the editorship). Geography of Georgia. Tbilisi (2000).

Tavartkiladze, K. and L. Shengelia: The modern climate change in Georgia. Mecniereba, Tbilisi(1999). 